\title{
PERSPECTIVE: PHYSIOLOGICAL BENEFITS OF SHORT-CHAIN FATTY ACIDS FROM CEREAL GRAIN FIBRE FERMENTATION AND METABOLIC SYNDROME
}

\author{
Guna Havensone ${ }^{1, \#}$, Laila Meija ${ }^{1,2}$, and Aivars Lejnieks ${ }^{1,3}$ \\ ${ }^{1}$ Rīga Stradinš̌ University, 16 Dzirciema Str., Rīga, LV-1007, LATVIA \\ 2 Pauls Stradiṇš Clinical University Hospital, 13 Pilsoṇu Str., Rīga, LV-1002, LATVIA \\ ${ }^{3}$ Rīga East Clinical University Hospital, 2 Hipokrāta Str., Rīga, LV-1038, LATVIA \\ \# Corresponding author, guna.havensone@gmail.com
}

Contributed by Aivars Lejnieks

\begin{abstract}
Currently, intervention studies in humans have demonstrated that dietary fibre and whole grain consumption increase gut bacterial diversity. However, low-fibre intake drives depletion of the human gastrointestinal microbiota and indirectly stimulates metabolic abnormalities linked to metabolic syndrome insulin-resistance and abdominal obesity. The aim of the current paper was to summarise current evidence for the effect of consumption of cereal fibres on gut microbiota composition and their metabolites. By increasing the daily consumption of cereal fibre, the gut microbiota diversity should have positive impact on the host's health.
\end{abstract}

Key words: dietary fibre, cereal fibre, gut microbiota, prebiotic, postbiotic.

\section{INTRODUCTION}

Metabolic syndrome (MetSyn) is a variety of metabolic abnormalities linked to insulin-resistance and abdominal obesity. From the perspectives of both individual clinicians and the health of the general public, MetSyn is the major contributor to the global epidemic prevalence of Type II diabetes mellitus (T2D) and cardiovascular diseases. MetSyn prevalence is high, affecting $20 \%$ to $30 \%$ of the general population (Sherling et al., 2017), and increases with age; about $40 \%$ of adults aged 40 and older have MetSyn (Pucci et al., 2015).

Dietary changes and increased physical activity aimed at normalising body weight are well recognised as first-line therapy for MetSyn and all its individual components. Undoubtedly, dietary strategies for modulating postprandial glycemic control and inflammation are tools for the management and prevention of MetSyn. One of the dietary strategies is to normalise gut microbial composition. Increasing evidence suggests that the gut microbiota contributes to MetSyn through the modulation of the host energy. Studies on humans have shown that obesity is associated with phylum-level changes in gut microbiota, including the reduction of the Bacteroidetes/Firmicutes ratio (Hoda et al.,
2017). Some studies have shown that the proportions of bacteria present in these phyla may contribute to metabolic outcomes in the host, partly by altering the amount and type of short-chain fatty acids produced. Differences in gut microbiota have been reported in individuals with MetSyn, with lower levels of butyrate-producing bacteria than in healthy individuals. In addition, a specific protective action in relation to MetSyn was observed in the case of a specific bacterium, Akkermansia muciniphila, which was shown to both reduce chronic subclinical inflammation and to improve insulin sensitivity. Studies have reported that a healthy diet can improve the efficacy of gut microbiota intervention for MetSyn treatment (Pascale et al., 2018). In this light, according to the scientific evidence available in the literature, habitual whole-grain consumption is suggested as the main source of dietary fibre (DF) that may help to achieve this goal. In Latvia, as well as in most other northern European countries, cereal products are the main contributor of carbohydrates and DF (Meija et al., 2013).

\section{DIETARY FIBRE IN WHOLE — GRAIN CERENALS}

The DF fraction of cereals consists of non-starch polysaccharides (NSPs), resistant starch (RS), oligosaccharides 
(mostly fructans) and the non-carbohydrate polyphenolic lignin. The main NSPs in cereals are arabinoxylans, $\beta$-glucan, and cellulose. These polymers are present in the cell walls, along with lignin, lignans, phenolic acids, and minor amounts of protein (Bach Knudsen, 2015). The physicochemical characteristics of cereal fibres include fermentability, solubility, and viscosity. These properties influence the therapeutic effects due to their consumption. (Holscher, 2017). Accordingly, the impact of cereal DF on glycaemic response can be divided into acute therapeutic effects coming its properties like water dispersibility, viscosity, and bulk, and secondary effects like fermentability into short-chain fatty acids (SCFA).

In fact, there is convincing evidence that glycaemic control,

Table 1. Starch and NSP content of whole grain from wheat, rye, and oats

\begin{tabular}{lcccc}
\hline \multicolumn{1}{c}{ Whole grain } & Wheat & Rye & Oats \\
\hline Dietary fibre, g/kg DM & 139 & 202 & 96 \\
Total NSPs, g/kg DM & 124 & 185 & 76 \\
Fructans & 9 & 31 & 1 \\
Cellulose & 19 & 13 & 6 \\
ß-glucan & 6 & 20 & 38 \\
Arabinoxylan & 71 & 96 & 21 \\
Others & 19 & 25 & 10 \\
Lignin, g/kg DM & 15 & 17 & 20
\end{tabular}

DM dry matter; NSP nonstarch polysaccharide

*The sum of noncellulosic residues galactose, galactose, mannose, uronic acids, and glucose not accounted for as $\beta$-glucan or cellulose.

satiety, and subsequent weight loss are mediated directly by the combination of fermentable and non-fermentable fibres. The structure and composition of cereal grains DF are different: the structure of wheat is closer to that of rye, than to the structure of oat (Bach Knudsen, 2015) (Table 1).

Insoluble cellulose and highly branched arabinoxylans lead to increased gut transit, which will reduce the amount of time available to absorption of glucose in the small intestines. The luminal viscosity created by soluble $\beta$-glucan and soluble arabinoxylans may prolong digestion and absorption and thereby lower starch hydrolysis. NSPs and lignin that escape digestion in the small intestine and pass to the colon are fermented by the colonic microbiota. The process of fermentation involves the hydrolysis of NSPs. The degradation of carbohydrates by the microbial community in the colon occurs in a hierarchic sequence: sugar residues = oligosaccharides $>$ starch residues $>$ soluble NSPs $>$ insoluble NSPs. Fermentation in the large intestine leads to the production of SCFA, mainly acetate, propionate and butyrate, gases and other metabolites, including lactate and pyruvate (Bach Knudsen, 2015; Alexander et al., 2017).

\section{MICROBIOTA AND SCFA METABOLISM}

The ileum and ascending colon are the most active sites for fermentation and with the lowest $\mathrm{pH}$ (5.4-6.4), depending on the rate of fermentation (due to high levels of produced SCFA). The ratio of SCFA production and absorption depend on fermentation substrate, microbial composition as well as colonic transit time. For example, bacteria within the Bacteroidetes phyla are known to be able to utilise arabinoxylan fibre fractions in rye and to produce mostly butyrate. Fermentative end-product acetate accounts for approximately two-thirds of the produced SCFAs, propionate, and butyrate, in the ratio of $60: 20: 20$, respectively (Bach Knudsen, 2015). Acetate is formed by lots of the bacteria groups that are present in the colon, while bacterial groups that form propionate and butyrate are more restricted. Firmicutes, Bacteroidetes, and Actinobacteria are the dominant bacterial species that inhabit the colon. Firmicutesspore forming bacteria, which typically amount to 64-78\% of the Western human microbiota, include helpful species, such as Lactobacillus, and pathogenic species like Clostridium. Bacteroidetes- opportunistic pathogens (e.g., Bacteroides) are dominant in populations with higher protein and fat intake. Prevotellae dominate in those consuming high levels of fiore and typically amount to $13-28 \%$ of human gut microbiota in Western populations. Actinobacteria produce metabolites with antibacterial/viral function (e.g., Bifidobacterium) and amount to 3-5\% of human gut microbiota in Western populations (Jefferson and Adolphus, 2019). Recent research highlights the roles of low bacterial diversity and ratio between Firmicutes: Bacteriodetes in causing unwanted weight gain (Jefferson and Adolphus, 2019). It is explained through the mechanism whereby the fermentation of prebiotic (plant-based diet) generates more acidic conditions in colon, supporting better growth of butyrate-producing Firmicutes, at the same time reducing the proliferation of the acid sensitive Bacteroides.

SCFAs provide an energy source for microbial growth and a variety of physiologic effects for the host; thus $>90 \%$ of SCFAs are either metabolised by the microbiota for energy or absorbed by enterocytes. Only $5 \%-10 \%$ is excreted in faeces (Celeste et al., 2017). Once absorbed, SCFAs may be used by the enterocyte for energy (butyrate is preferentially) or released into the portal circulation for utilisation by peripheral tissues, e.g., liver. Significant uptake of propionate and butyrate (but not of acetate) by the liver was reported (Vetrani et al., 2016). SCFAs also act as secondary messengers that regulate gene expression and stimulate anorectic hormone and gut peptide synthesis, glucagon-like peptide 1 (GLP-1), and initiate other signal transduction pathways in peripheral tissues (i.e., increased insulin sensitivity, reduced cholesterol synthesis). The mechanisms appear to involve adipocyte cell differentiation, regulation, and metabolism. SCFAs further inhibit lipolysis within adipose tissue as indicated by the reduced plasma concentrations of nonesterified fatty acids (FAs) after the intake of fermentable carbohydrates. The consequence is reduced availability of FAs for uptake into ectopic fat depots (e.g., liver, skeletal muscle) (Ingerslev et al., 2014). SCFAs also act to decrease inflammation. In fact, butyrate has been proposed to reduce systemic inflammation by the maintenance of the intestinal epithelial barrier. Recent evidence has suggested that intestinal permeability and unhealthy gut microbial diversity al- 
low unfavourable bacterial strains or their metabolites to cross the intestinal barrier and invade the surrounding tissue, thereby stimulating an innate immune system response (Mc Nabney and Henagan, 2017). Thus, SCFAs have been linked to prevention of metabolic abnormalities of MetSyn.

\section{IMPACT OF WHOLE-GRAIN COMSUMPTION ON MICROBIOTA COMPOSITION AND ITS METABO- LISM}

The prebiotics of cereal grains have a large molecular weight and most of them have poor water solubility, which makes them difficult to be fermented. However, several studies showed that $\beta$-glucan, arabinoxylans, RS can be regulatory factors that result in changes in the microbiota (species diversity or abundance) and SCFA production in colon as a metabolic indicator of microbiota fermentation (Celeste et al., 2017). Not only the complexity of cereal fibres, but also processing of grain (e.g., milling, heating, flaking, or extrusion), affect the stage of fermentation.

A current systematic review by Jefferson and Adolphus (2019) supports the role of habitual diet (a daily cereal fibre consumption) in modulating both the microbiota composition and also its metabolism, which could help to maintain health today and improve health in the future. Currently, clinicians promote low carbohydrate diets that contribute to breakdown of excess fat stores and improvement in insulin sensitivity to patients with MetSyn. Recently, studies highlighted that this results in lower microbiota diversity. In fact, cereal fibre can stimulate of colon microbiota at relatively low levels, as little as $5.7 \mathrm{~g}$ of wheat fibre, $10 \mathrm{~g}$ barley fibre, and $7 \mathrm{~g}$ rye fibre (Jefferson and Adolphus, 2019). Even a relatively a simple change in eating habits like consumption of cereal grain at breakfast can boost a single bolus of fibre and provide stimulatory effects on the gut microbiota.

\section{CONCLUSIONS}

Thanks to the cereal fibre complexity, grain bran has been described as an ideal "dinner table" for bacteria. Cellulose and highly branched arabinoxylans are resistant to fermentation and are proposed to act as a physical surface or "table" for which bacteria attach. Fermentable substances in the cereal bran particle (such as starch, proteins and less substituted arabinoxylans) then provide the "dinner" for these attached bacteria (Jefferson and Adolphus, 2019).

\section{REFERENCES}

Alexander, C., Swanson, K. S., Fahey, G. C., Garleb, K. A., (2017). Perspective: Physiologic importance of short-chain fatty acids from nondigestible carbohydrate fermentation. Adv, Nutr., 10 (4), 576-589.

Bach Knudsen, K. E. (2015). Microbial degradation of whole-grain complex carbohydrates and impact on short-chain fatty acids and health. Adv, Nutr., 6 (2), 206-213.

Hoda, M., Wright, M. L., Anil Kumar, N. V., Qawasmeh, Abdel, Hassan Sherif T. S., Mocan, A., Nabavi, S. M., Rastrelli, L., Atanasov, A. G., Haddad, P. S. (2017). Significance of microbiota in obesity and metabolic diseases and the modulatory potential by medicinal plant and food ingredients. Front Pharmacol., 8, 387.

Holscher, H. D. (2017). Dietary fibre and prebiotics and the gastrointestinal microbiota. Gut Microbes, 48 (2), 172-184.

Ingerslev, A. K., Theil, P. K., Hedemann, M. S., Lærke, H. N., Bach Knudsen, K. E. (2014). Resistant starch and arabinoxylan augment SCFA absorption, but affect postprandial glucose and insulin responses differently. Brit. J. Nutr., 111 (9), 1564-1576.

Jefferson, A., Adolphus, K., (2019). The effects of intact cereal grain fibres, including wheat bran on the gut microbiota composition of healthy adults: A systematic review. Front Nutr., 633

McNabney, S. M., Henagan, T. M., (2017). Short chain fatty acids in the colon and peripheral tissues: A focus on butyrate, colon cancer, obesity and insulin resistance. Pharmacol. Res., 120, 34-42.

Meija, L., Soderholm, P., Samaletdin, A., Ignace, G., Siksna, I., Joffe, R., Lejnieks, A., Lietuvietis, V., Krams, I., Adlercreutz, H. (2013). Dietary intake and major sources of plant lignans in Latvian men and women. Int. J. Food Sci. Nutr., 64 (5), 535-543.

Pascale, A., Marchesi, N., Marelli, C., Coppola, A., Luzi, L., Govoni, S., Giustina, A., Gazzaruso, C. (2018). Microbiota and metabolic diseases. Endocrine, 61, 357-371.

Pucci, G., Alcidi, R., Tap, L., Battista, F., Mattace-Raso, F, Schillaci, G. (2017). Sex- and gender-related prevalence, cardiovascular risk and therapeutic approach in metabolic syndrome: A review of the literature. Pharmacol. Res., 120, 34-42.

Sherling, D. H., Perumareddi, P., Hennekens, C. H. (2017). Metabolic syndrome: Clinical and policy implications of the new silent killer. $J$. Cardiovasc. Pharmacol. Ther., 22 (4), 365-367.

Vetrani, C., Costabile, G., Luongo, D., Naviglio, D., Rivellese, A. A., Riccardi, G., Giacco, R., (2016). Effects of whole-grain cereal foods on plasma short chain fatty acid concentrations in individuals with the metabolic syndrome. Nutrition, 32 (2), 217-221.

Received 26 January 2020

Accepted in the final form 18 March 2020

\section{PERSPEKTĪVA: GRAUDAUGU ŠKIEDRVIELU FERMENTĀCIJAS PRODUKTU — ĪSO KĒŽU TAUKSKĀBJU SPĒJA MODELĒT VIELMAIN̦AS IZMAIN̦AS, KURAS SAISTITTAS AR METABOLISKO SINDROMU}

Pēdējos gados uztura intervences pētījumi norāda, ka tieši pilngraudu produktu lietošana un graudaugu škiedrvielu daudzums uzturā vistiešākā veidā ietekmē zarnu mikrobiotu, tās daudzveidību — "veselību", savukārt, diētas ar zemu ogḷidrātu sastāvu (mazs škiiedrvielu daudzums) samazina zarnu trakta mikrobiotu un netieši stimulē metaboliskas izmainas, kas saistītas ar metabolisko sindromu — insulīna rezistenci un aptaukošanos. Ši raksta mērkis ir izanalizēt pašreizējos pierādījumus par graudaugu škiiedrvielu ietekmi uz zarnu mikrobiotas sastāvu un tās metabolītiem. Ikdienā vairāk patērējot pilngraudu produktus, var modelēt zarnu mikrobiotas daudzveidību un labvēlīgi ietekmēt saimnieka veselību. 